\title{
«VISIBILIZAR EL BORDE» ENTReVISTA a Ángeles Rocha
}

Ángeles Rocha (Santiago de Chile, 1971), fotógrafa y poeta. Entre sus numerosas exhibiciones: «Desenfocada: Imágenes de India» (Festival de las Artes de Valparaíso, Chile), «Nosotras. Imágenes audiobiográficas» (Centro Cultural Jaaga, en Bangalore, India), «Cuerpos ineludibles» (Cárcel de Alto Hospicio, Iquique, Chile), «Fiesta de San Lorenzo. Apuntes para una arqueología trans» (Universidad Católica de Valparaíso, Chile), "Cicatrices de género» (Universidad Católica de Valparaíso, Chile), «Zona de derrumbe. Detalles de Santiago en ruinas» (Biblioteca de Santiago, Chile) y una «Muestra retrospectiva» (Outhouse, Dublín, Irlanda). Su libro de poesía El reyno fue publicado en 2013. Su obra ha recibido premios en la revista Pluma y Pincel y en Radio Umbral. Su próximo libro, Dèjá Vu, es una colección de relatos breves. Rocha ha vivido en India, Brasil, México y actualmente se encuentra en Dublín (Irlanda), donde está trabajando en un nuevo proyecto.

\section{Texto: A. L. MentXaka}

Tu práctica artística se ha enfocado en el viaje y la documentación, con algunas excepciones. Entre otros proyectos, has documentado una «romería abyecta» en «Apuntes para una arqueología trans», en la fiesta de San Lorenzo en el desierto de Atacama en Tarapacá (Chile); varios encuentros e intervenciones activistas en La Paz (Bolivia), Santiago de Chile y Caracas; la manifestación de la feminidad en mujeres trans prisioneras en la cárcel de Alto Hospicio en Iquique (Chile); las trazas gesturales de la figura paterna en el proyecto «Cicatrices de género», que se realizó en Santiago de Chile; y en otro ensayo en colaboración con Rebeca Miller titulado «Nosotras: Imágenes audiobiográficas» has documentado la experiencia de ungrupo demujeres «invisibles» en Bangalore(India). Y ahora has venido a Dublín. Hay una tradición de la poeta y el poeta viajeros, «trovadores» de ideas, y en Irlanda también tenemos una tradición de cantantes de baladas políticas en el siglo XIX que por un tiempo, en la zona de Connaught, eran mayormente mujeres. ¿Te situarías en una tradición de trovadores políticos? Sí. Creo que el arte es un dispositivo político, biopolítico, no es proselitismo partidista. El arte debe dar testimonio de una época, de una historia, y debiera dar luces sobre la misma.

Tras varios años de proyectos fotográficos - algunas veces relacionados con proyectos educativos o de desarrollo, pero siempre de investigación-, en 2013 publicaste tu primer libro de poesía, EI reyno, sobre los ejecutados, torturados, desaparecidos y exiliados durante la dictadura en Chile. ¿Marcó este libro un nuevo rumbo en tu carrera?

Más que marcar un nuevo rumbo, es mi manera de cristalizar una realidad y un sentimiento enquistado en el alma latinoamericana, no solo chilena. Chile vivió un golpe de Estado, pero fue una más de todas las dictaduras latinoamericanas. El libro fue escrito a fines de la década de los noventa y estuvo diez años en un cajón. Decidí esperar para ver si merecía la pena, si tenía valor y si las palabras sobrevivirían al tiempo. Diez años después lo leí de nuevo y pensé que había que publicarlo. No me interesa publicar por publicar, solo quiero publicar aquello sobre lo 
que esté segura de que allí se está enunciando alguna verdad, si hay corazón en el libro. Mira, Juan Rulfo -que también era fotógrafo-solo publicó dos libros y eso puede ser suficiente.

Tu poesía parece ofrecer una forma alternativa de historiografía: poesía como testimonio. En ese sentido es como el resto de tu obra, excepto que en esta ocasión en lugar de mirar al presente miras al pasado. Sí. Efectivamente, es un relato testimonial, histórico y universal al mismo tiempo. La luz de la palabra y del arte mantiene vivo el relato de la historia.

¿Te consideras principalmente fotógrafa? ¿Poeta? ¿Artista?

Yo digo que «saco fotos» o que «escribo poesía». No me gusta la palabra «artista». "Soy artista» no me suena bien. Aunque yo me siento poeta, eso sí. El tono, la atmósfera..., me gusta vivir en la poesía. Es volver al instante, a la belleza de lo mínimo, de lo cotidiano... y acercarse a ver qué hay allí. Y me inventé el nombre de fotopoeta -por eso, porque me gusta unir la poesía y la imagen-. Me sienta bien crear esa categoría para hermanar e interpelar el ejercicio de las dos artes. Yo soy fotopoeta. Mis fotografías también pueden ser poemas. Y la poesía siempre tiene algo de fotografía.

En tu obra fotográfica, ¿por qué prefieres la fotografía análoga?

Es otra estética y otra ética. Ética es estética. Con una cámara análoga tienes que pensar antes de sacar una foto; la fotografía digital es casi una expresión o una metáfora del capitalismo: sacas todas las fotos que quieras, incluso si no las necesitas, con lo que no tienes que pensar, planear, ni siquiera querer sacar una foto. La fotografía digital es inmediata, cercana al consumo de las imágenes y a la ansiedad de las mismas, es como un acto bulímico. Este acto bulímico lo puedes ver en otras instituciones, como, por ejemplo, la escuela. Desde mi formación como maestra de español hace un par de años conocí la teoría pedagógica que está desarrollando María Acaso en España, la que critica la educación bulímica, aquella educación que te hace deglutir contenidos y luego vomitarlos en una evaluación. Por otra parte, la fotografía análoga es económica, reflexiva, introspectiva y como resultado ofrece mucha más riqueza desde lo material, ya que puedes ver los haluros de plata en las imágenes capturadas en blanco y negro. Actualmente, hay muchos fotógrafos trabajando con película por lo mismo.

Me parece que hay algo en común entre tus poemas y la obra de la artista colombiana Doris Salcedo, que vimos recientemente en el Irish Museum of Modern Art («Acts of Mourning», julio de 2019). Parece que hay un patrón que se repite en la historia de los países latinoamericanos: la devastación del imperialismo,

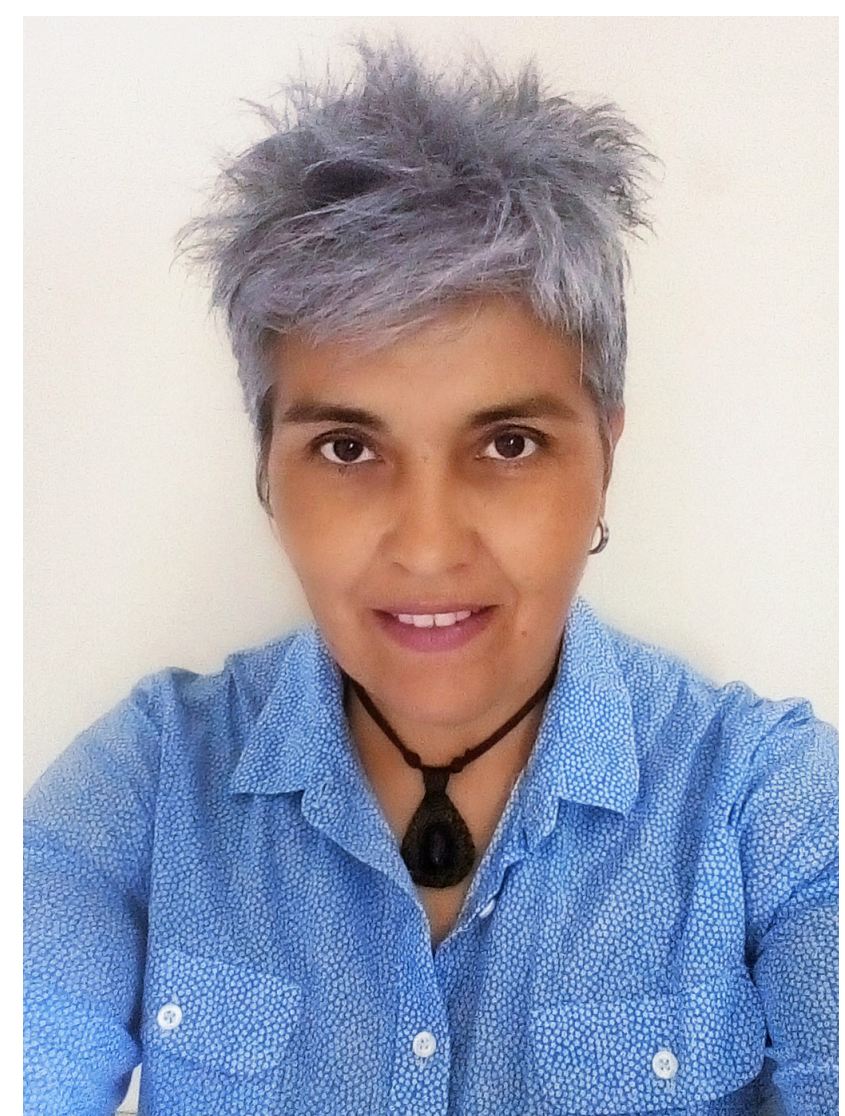

La entrevistada Ángeles Rocha. Foto de la autora.

la demolición de la cultura local, siglos de opresión, revueltas violentas, independencia, poco después dictadura y luego una sucesión de dictadura y democracia con períodos en los que la diferencia entre ambas no es siempre clara. Tus poemas sobre las secuelas de la dictadura en Chile restan énfasis a la ubicación de los hechos a los que se refieren: ¿te parece que hay una convergencia, en términos políticos, en Latinoamérica o incluso en el continente americano? Sí, yo creo que somos una sola región y hay muchas similitudes en los procesos sociales y políticos vividos en América Latina. Sin embargo, también veo convergencias a través del mundo con otros lugares que han sufrido experiencias parecidas, dictaduras o totalitarismos. Yo me siento latinoamericana. En los poemas de El reyno el lenguaje es un castellano más estandarizado que el que encuentras en el español hablado en Chile, con lo que puede aplicarse a otros lugares en Latinoamérica y más allá. El «reyno» es el reino de Dios, es la representación de la tradición cristiana en la cultura, cercana a la teología de la liberación, pero también es el imperio con la «y» del legado del imperio. Tuve la posibilidad de visitar la exposición de Doris Salcedo acá en el IMMA y efectivamente, como tú señalas, su increíble trabajo en honor y conmemoración de los caídos en Colombia me 


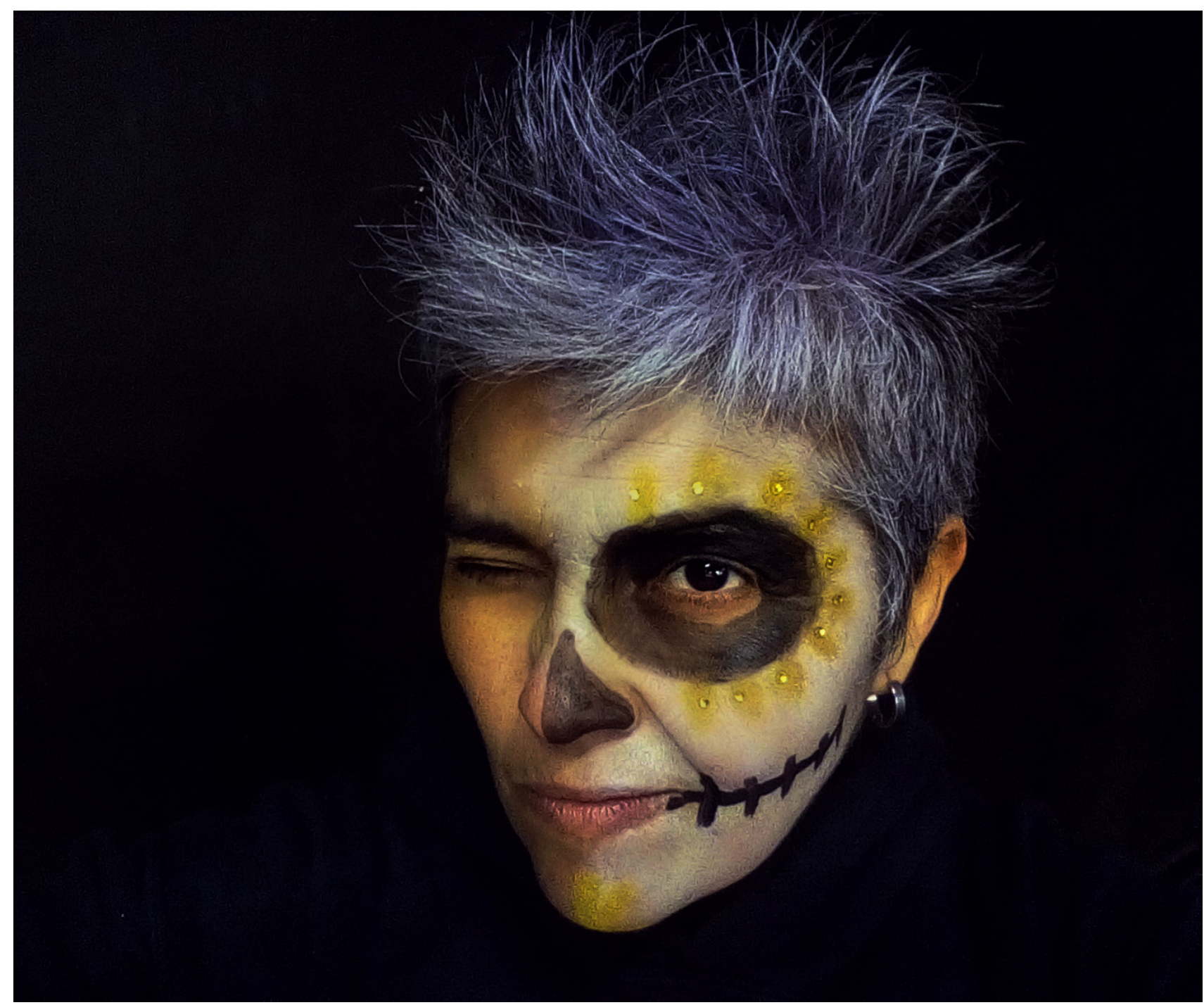

pareció muy hermano y análogo al mío en el libro. Pude leer fácilmente sus instalaciones porque somos parte de la misma historia y tenemos la necesidad de dejar un testimonio y de conmemorar a quienes sacrificaron sus vidas en tiempos de opresión.

¿Qué importancia tiene lo teórico en tu obra? Tienes un grado en literatura hispanoamericana y luego has realizado estudios de género. Te has referido a Judith Butler en tu proyecto fotográfico en India. Y tu trabajo también me ha hecho pensar en ideas como la «conciencia nomádica» de Rosi Braidotti o «la nueva mestiza» de Gloria Anzaldua en críticas de la identidad desde lo anticolonial, antiautoritario, no-normativo... Y quizá críticas de una identidad coherente, inmutable o incluso claramente definida. Yo definiría mi trabajo como una mirada disidente. El arte es un dispositivo político -el arte o, más bien, la creación-. El arte tiene que estar al servicio de la crítica cultural. Mi trabajo, el trabajo de los artistas, tiene que ser político. Mi libro no es inocente, la teo- ría está dentro. La teoría feminista, la pedagogía crítica, «la otra historia», «la historia de los nadie» según Eduardo Galeano u Octavio Paz.

¿Describirías tu trabajo como queer?

Mi trabajo tiene más lectura que lo no-normativo. Hay una mirada que es una. Y lo queer a menudo es solo una etiqueta, casi comercial, no exenta de problemas. Por ejemplo, el advenimiento de lo queer, como lente y como posición, le restó poder a lo lésbico, que tardó años en encontrar sitio.

En Euskadi, o Euskal Herria, la región a caballo entre España y Francia de donde yo soy, hay una tendencia a distanciarnos del imperialismo español -en parte porque la dictadura franquista copió la estrategia imperialista de diezmar la cultura nativa-, pero los vascos estuvieron completamente involucrados en el imperialismo histórico. En tu opinión, ¿cuál es el rol de quienes históricamente hemos estado del lado de quienes escriben la historia (en el contexto 
del proyecto del imperio), para desmantelar las estructuras de poder que facilitan esta zombificación del imperialismo, que nunca se acaba de morir?

El rol de las personas que están del lado de quienes han escrito la historia no es justificar la matanza, los siglos de opresión de todas las minorías. En estos momentos percibo que hay que realizar un trabajo introspectivo, consciente, meticuloso, personal y destituir ese imperio desde tus propias prácticas personales, que, sin duda, son políticas. Una feminista chilena llamada Julieta Kirkwood, ya en los años ochenta, tomó la idea de que «lo personal es político», pidiendo «democracia en el país y en la casa». $\mathrm{Si}$ una sola persona logra cambiar las lógicas del imperio desde su interior, esto se cuantifica y se expande, se duplica y se contagia.

\section{Tu próximo proyecto es literario.}

Estoy trabajando en un libro que está casi listo. Son veintidós relatos cortos traspasados por el tópico del viaje. Se llama Déjà vu. Agrupa crónicas de viaje y ficción. Es bastante más local, más cercano a la idiosincrasia chilena. El viaje se muestra desde distintos aspectos a través de medios conocidos, como el bus, la bicicleta, el barco, el avión; sin embargo, aparecen los sueños, las fantasías, los viajes místicos.

Dime algo sobre el contexto irlandés. Viniste a Irlanda en agosto de 2018 y esperas vivir aquí una temporada. En Irlanda tenemos una tradición de emigración a Estados Unidos, prácticamente institucionalizada tras la Gran Hambruna de 1845 -y también hay una tradición de exilio interno, en el origen de la cultura de la etnia traveller, que sé que te interesa-, pero no hay tanto tráfico entre Latinoamérica e Irlanda.

Yo creo que Irlanda y Chile son similares en cierto modo. Chile es una isla también. Mar al oeste, de- sierto al norte, montañas al este, el hielo al sur... Es más cerrada que otros países, más conservadora. En primer lugar me atrajo la literatura irlandesa -Beckett, Stoker...-, luego el saber que no iba al imperio, que no iba a Britain. Esa vieja animosidad contra lo británico que hay aquí, debida a la historia colonial, que es medio en broma pero también en serio, me gusta. Hay un resentimiento contra el imperio, lo que también encuentras en Chile, el país de los resentidos. Hace poco leí un texto buenísimo de un escritor chileno Ilamado Roberto Castillo: «Elogio al resentimiento». Finalmente, también está la arqueología, todos los tesoros arqueológicos, las ruinas, los montículos prehistóricos, etcétera, que están por todas partes en Irlanda. La arqueología es importante a nivel consciente: está visible.

Parece que estás psicoanalizando a los irlandeses.

Bueno, algo hay ahí que está enterrado, pero se encuentra a la vista. Eso es muy interesante. Y es por eso también que me gustaría hacer un proyecto sobre los travellers [un grupo étnico irlandés de nómadas que sufre una considerable discriminación en el país]. Espero conseguir fondos para realizar un proyecto fotográfico. Los discursos de esta comunidad están silenciados, ¿por qué? ¿Qué le recuerdan los travellers [a la población asentada de Irlanda]? ¿Qué tienen los Irish Travellers que los irlandeses no quieren ver? ¿Qué identidad primitiva les recuerda? ¿Algo que ya no tienen... porque ahora están en Europa? Hay algo aquí que sería digno de reconocer, develar, tensionar y liberar.

¿Qué es lo más importante en tu trabajo?

Visibilizar la marginalidad, el borde; hacer conciencia, comunicar algo y contar una historia verdadera. 